\title{
"The Influence of Academic Education on Crime Rate within South Asia": A Case Study from Pakistan
}

\author{
Moazzam Butt \\ National College of Business Administration \& Economics \\ DHA Campus Lahore, Pakistan \\ Sumaira Munir \\ National College of Business Administration \& Economics \\ DHA Campus Lahore, Pakistan \\ Sobia Arif \\ National College of Business Administration \& Economics \\ DHA Campus Lahore, Pakistan \\ Dr. Fareeha Zafar \\ Department of Computer Science \\ Government College University, Lahore. Pakistan
}

\begin{abstract}
This paper illustrates effects of academic education on the crime ratio prevailing in the South Asian countries. The study introduces practical impacts amongst crime and education in South Asian countries and particularly in Pakistan, utilizing different information sources. The paper shows positive relationship between education and crime. The result demonstrates that in the Pakistan there are not enough opportunities available to accommodate the educated people. The empirical evidences indicate that the criminal activities raises the financial benefits more than those opportunities offered to the educated people. This study concludes that if private and public sector provide sufficient opportunities to adjust all the educated people can yield significant social advantages and can be a key approach device in the drive to diminish crime.
\end{abstract}

\section{INTRODUCTION}

With common public of around 1.4 billion South Asia is home to world's half South Asia is the universes' most vigorously populated district. South Asia as a locale comprises of eight nations Pakistan, Afghanistan, India, Sri Lanka, Maldives, Nepal, Bangladesh and Bhutan. Best climatic conditions and geostrategic areas raise the significance of these nations. The area has wide assortment of assets rotating from common assets to refined data innovation asset based. The consolidated GDP of each of the eight nations is around USD 1.8 trillion and for every capita GDP is somewhat over USD 1000. The territory has wide instructive and modern base to raise the financial capability of the locale.

Driven by powerful development in India, South Asia demonstrates flexibility notwithstanding turbulent universal markets and remains the quickest developing district on the planet, with financial development anticipated to bit by bit quicken from 7.1\% in 2016 to $7.3 \%$ in 2017, a World Bank report said. Financial development anticipated that would step by step quicken to $7.3 \%$ in 2017 from $7.1 \%$ in 2016. 
Criminologists and educators have long speculated that increasing the educational achievement might lower the probability to engage in criminal activities. There are a number of reasons for expecting a relationship between education and crime. First, and most important is, higher education increases the economic returns to legitimate work. Second, higher education may directly increase the intuitive cost of committing crime. Finally, higher education could change preferences in indirect ways. For example, education may help people to better understand all the consequences of their decisions, an ultimately make them more far-sighted and/or more risk adverse.

Enhancing instruction can yield noteworthy social advantages and can be a key arrangement device in the drive to decrease crime(Machin, Marie and Vujic, 2011). The finishing secondary school lessens the likelihood of imprisonment by around .76 rate focuses for whites and 3.4 rates focuses for blacks(Lochner, Moretti, 2001). The expanded school graduation rates relates to a noteworthy abatement in the crime rate Gonzalez (2015). Expanded secondary school graduation rates do deliver a huge diminishing in crime rates and are monetarily productive in lessening remedies costs(Lochner and Moretti, 2004). School participation decreases contemporaneous property crime yet increments contemporaneous savage crime among adolescents (Lochner, 2007).

In this study we are going to analyse the relationship between higher education and crime rate in Pakistan region. In order to examine the impact of education on crime, the crime categories included are of extreme type (killing, rape, theft, and attack) and property (looting, stealing of motor vehicle theft) and selected level of education is higher education.

\section{LITERATURE REVIEW}

Gonzalez (2015) concentrated on instruction as an ex-bet crime lessening component. He particularly, researches whether increments in instruction levels relate with crime diminishment. He utilized board investigation approach, which takes a gander at crime crosswise over years and countries including both those that are created and those that are creating. He concentrated on school graduation and shifting levels of instructive accomplishment, he test the degree to which training diminishes crime and found that expanded school graduation rates relates to a noteworthy abatement in the crime rate. A 5\% expansion in the school graduation rate, for example, creates a $18.7 \%$ lessening in the murder rate.

Machin, Marie and Vujic (2011) inspected that the crime decreasing capability of training, displaying causal measurable evaluations based upon a law that changed the obligatory school leaving age in England and Wales. They outline the investigation in a relapse irregularity setting and reveal huge abatements in property crime from decreases in the extent of individuals with no instructive capabilities and increments in the period of leaving school that came about because of the adjustment in the law. They find that enhancing instruction can yield noteworthy social advantages and can be a key arrangement device in the drive to decrease crime.

Lochner (2008) inspected that an expansion in instructive fulfilment fundamentally decreases resulting fierce and the criminal attitude of people has lessened for the benefit of the society. Tutoring has little beneficial outcomes on salaried crime. School participation decreases contemporaneous property crime yet increments contemporaneous savage crime among adolescents. Detainment amid late puberty seems to decrease instructive achievement.

Feinstein and Sabates(January 2005) give an exact assessment of the extra advantages that an instructive program, for example, the EMA(Education Maintenance Allowance), may have as 
far as crime lessening. The EMA program was intended to build investment in post-obligatory training and guided in 15 LEAs(Local Education Authorities) in 1999. They have utilized range level information on feelings for male adolescent thievery, burglary and fierce crimes (16 to 18 years of age) from 1996 to 2002 to assess whether the EMA program has had thump on impacts as far as crime lessening. Utilizing contrast apathies estimation strategies, comes about demonstrated that male conviction rates for thievery and burglary offenses fell more in the 15 LEAs that steered the EMA program than in whatever remains of the LEAs in England.

Lochner and Moretti (2004) have tended to the effects of optional training on crime rates through a generally monetary, cost investigation focal point. Their study has demonstrated that expanded secondary school graduation rates do deliver a huge diminishing in crime rates and are monetarily productive in lessening remedies costs.

Bazos and Hausman( March, 2004 ) think about the cost per crime forestalled by remedial instruction to the cost per crime anticipated through imprisonment. As per the after effects of the 'Three State' think about, restorative training is in charge of a $10 \%$ decrease in recidivism. They discover a $\$ 1$ million interest in imprisonment will forestall around 350 crime, while that same interest in training will avert more than 600 violations. Restorative instruction is twice as financially savvy as imprisonment.

Lochner, Moretti (2001) appraise the impact of secondary school graduation on investment in criminal movement representing endogeneity of tutoring. They start by breaking down the impact of secondary school graduation on imprisonment utilizing Census information.Instrumental variableevaluation utilizing changes as a part of state obligatory participation laws as an instrument for secondary school graduation reveal a critical diminishment in detainment for both blacks and whites. By and large, the appraisals propose that finishing secondary school lessens the likelihood of imprisonment by around .76 rate focuses for whites and 3.4 rates focuses for blacks.

\section{Education}

"Instruction is a deliberate procedure through which a youngster or a grown-up procures information, experience, expertise and sound mentality. It makes an individual socialized, refined, refined and instructed. For an enlightened and mingled society, instruction is the main means. It will likely make an individual great. Each general public offers significance to instruction since it is a panacea for all disasters. It is the way to tackle the different issues of life."

"Training is just the conveyance of learning, aptitudes and data from educators to understudies, is deficient to catch what is truly essential about being and getting to be instructed."

\section{Educational Ratio of South Asian Countries}

Insights of various nations demonstrated that instructive proportion is expanding in South Asian nations as they are spending more on height of training. Subtle elements of instructive proportion of South Asian nations are given underneath. The following table shows the crime ratio of South Asian Countries. 
Table 1 Educational Ratio of South Asian Countries

\begin{tabular}{|l|l|}
\hline South Asian Countries & Crime ratio \\
\hline Afghanistan & $38.2 \%$ \\
\hline Bangladesh & $61.5 \%$ \\
\hline Bhutan & $63 \%$ \\
\hline Maldives & $98 \%$ \\
\hline Nepal & $57.4 \%$ \\
\hline Pakistan & $60 \%$ \\
\hline Sri Lanka & $92 \%$ \\
\hline India & $74.04 \%$ \\
\hline
\end{tabular}

\section{Educational Ratio in Pakistan}

Pakistan is dedicated to prop up education and literacy rate, it is found that in FY2015, literacy rate is much more in big cities (76 percent) than in countryside( 51 percent). Area insightful information proposes that Punjab beats other provinces with 63 percent, $2^{\text {nd }}$ is Sindh with $60 \%, 3^{\text {rd }}$ is Khyber Pakhtunkhwa with $53 \%$ and the last is Balochistan with $44 \%$. During 2015, literacy rate for men was $70 \%$ and for women was $49 \%$.

GER (Gross Enrollment Rates) at the vital level barring Katchi (prep) for the age bunch 5-9 years at national level amid FY2015 recorded at 89.0 percent. The lessening in general GER in Pakistan is because of decrease in Punjab GER to 97 percent in FY2015 from 100 percent in FY2014. Sindh indicated change to 79 percent in FY2015 against 76 percent in FY2014 and Khyber Pakhtunkhwa additionally enhanced to 90 percent in FY2015 against 89 percent in FY2014 while Balochistan GER saw critical change to 71 percent in FY2015 when contrasted with 67 percent in FY2014.

NER at the national level amid FY2015 stayed stable at 57 percent. Region shrewd correlation uncovers that Punjab NER declined to 61 percent in FY2015 when contrasted with 64 percent in FY2014. Sindh NER enhanced to 51 percent in FY2015 when contrasted with 48 percent in FY2014; while NER of Khyber Pakhtunkhwa saw a slight change at 56 percent in FY2015 when contrasted with 54 percent in FY2014. Balochistan likewise saw a huge change at 46 percent in FY2015 when contrasted with 39 percent in FY2014.At national level, the aggregate number of enrolments amid FY2015 was recorded at 43.95 million when contrasted with 42.09 million amid a similar period a year ago. This demonstrates an expansion of 4.4 percent and it is evaluated to increment to 45.17 million amid FY2016.The add up to number of establishments remained at 252.56 thousands amid FY2015 when contrasted with 241.61thousands amid a year ago, demonstrating an expansion of 4.5 percent. Be that as it may, the quantity of organizations is assessed to increment to 257.47 thousands amid FY2016.The add up to number of educators amid FY2015 was recorded at 1.59 million when contrasted with 1.53 million amid a year ago demonstrating an expansion of 3.9 percent. This number of educators is assessed to expand further to 1.62 million amid the year FY2016. Public Expenditure on Education as rate to GDP is assessed at 2.2 rate in FY2015 when contrasted with 2.1 rate of GDP in FY2014 demonstrating an expansion of 4.8 percent. HEC is likewise adding to assume its part in running distinctive grants program to upgrade scholarly capability at different levels on legitimacy premise in accordance with particular criteria. Amid FY 2016, general 42,963 grants were granted under various projects of HEC. PM's Fee Reimbursement Scheme for less created ranges (chose districts) was effectively executed, and is preceded for FY 2016. Repayment to around 23,458 understudies of less created ranges is being done for the current year. PSDP distribution for HEC was Rs.19.985 billion in FY2016 for 144 (87 on-going and 57 new unapproved) improvement ventures being executed in Public Sector. Amid July 2015 to 
March 2016, the legislature has discharged Rs.14.053 billion (which is $70 \%$ of the updated allotment) for the execution of improvement undertakings reflected under PSDP 2015-16.

The following table represents the enrolment at different levels in Pakistan.

Table 2 Educational Ratio in Pakistan:

\begin{tabular}{|l|l|}
\hline Category & $\begin{array}{l}\text { Gross } \\
\text { Enrolment }\end{array}$ \\
\hline Pre-Primary & 9.59 Million \\
\hline Primary(I-V) & 19.8 Million \\
\hline Middle(VI-VIII) & 6.6 Million \\
\hline Secondary(IX-X) & 514.2 Thousand \\
\hline $\begin{array}{l}\text { Higher Secondary(XI- } \\
\text { XII) }\end{array}$ & 1.67 Million \\
\hline Degree College & 1.14 Million \\
\hline Higher Education & 1.30 Million \\
\hline
\end{tabular}

Source: Pakistan Economic Survey 2015-16

\section{Crime}

"A crime is an offense against an open law. This word, in its most broad sense, incorporates all offenses, yet in its more constrained sense is restricted to lawful offense."

Criminologist Paul Tappan characterizes crime as "a deliberate demonstration or exclusion disregarding criminal law ... , carried out without resistance or defence, and endorsed by the state as a lawful offense or crime."

\section{Crime Index of South Asian countries}

There is no current country that does not battle with crime. It is a social sick that has been considered crosswise over controls while at the same time tormenting social orders and their kin. Crime file of South Asian nations are seen as take after:

Table 3 Crime Index of South Asian countries

\begin{tabular}{|l|l|}
\hline South Asian Countries & Crime index \\
\hline Bangladesh & $67.43 \%$ \\
\hline Maldives & $46.36 \%$ \\
\hline Nepal & $40.89 \%$ \\
\hline Pakistan & $56.39 \%$ \\
\hline Sri Lanka & $45.79 \%$ \\
\hline India & $44.81 \%$ \\
\hline
\end{tabular}


Figure 1 Crime Index of South Asian countries

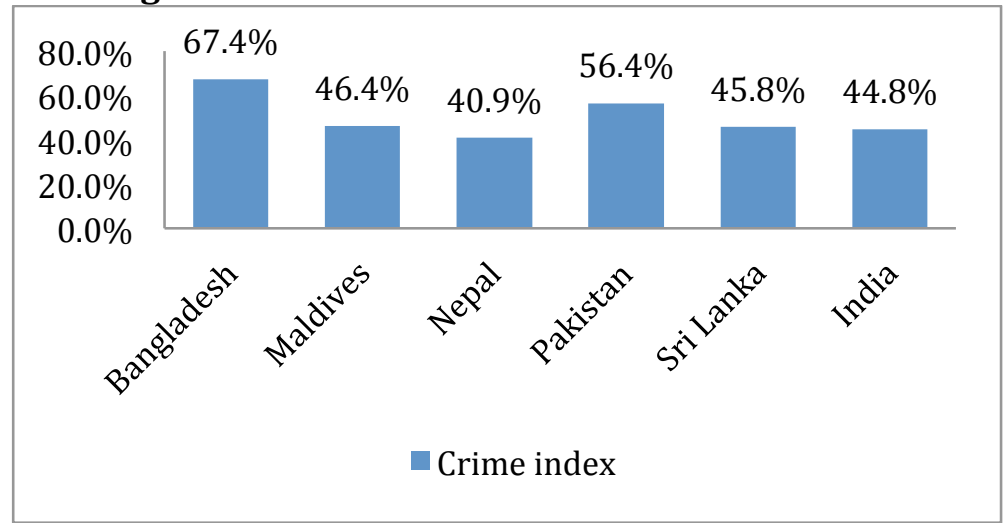

\section{Growth Rate}

Figure 2 Real GDP Growth in South Asian Countries

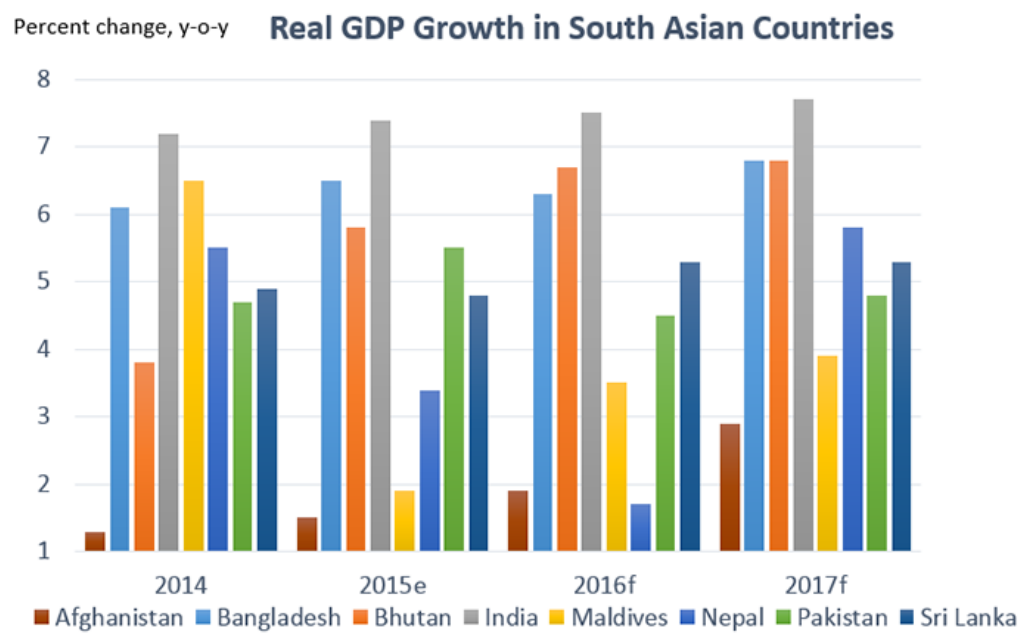

All countries in South Asian region are growing with rapid speed.This bar demonstrates that India has the most elevated development rate and Afghanistan has the least development rate. Numerous South Asian nations indicate potential for quickened development in the short to medium term. Be that as it may, the tailwinds of large amounts of settlements combined with low oil costs might back off so nations ought to be all around arranged for a more troublesome worldwide environment.

\section{Growth Rate in Pakistan}

Pakistan's economy kept on keeping up its development force in the monetary year 2015-16. The steady working up of the development force recommends that venture recuperation is more manageable. The development that the economy has managed for most recent couple of years is supported by dynamism in industry, agribusiness and administrations bolstered by solid development in residential request.

The FY2014 saw development of 4.05 percent, this development execution proceeded in FY2015 as GDP recorded a development of 4.04 percent and in FY2016 GDP development is assessed at 4.71 percent. This is the most noteworthy development accomplished since FY2009. 
Figure 3 Real GDP Growth in Pakistan

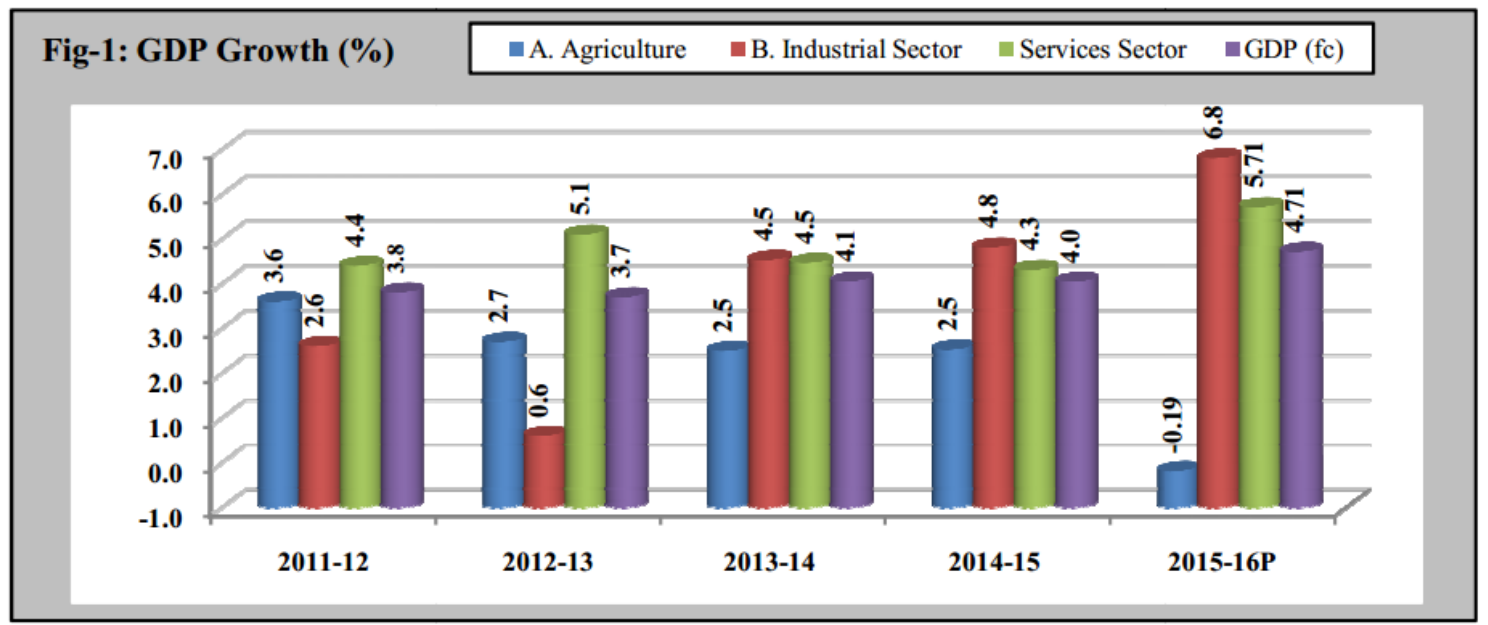

Source: Pakistan Economic Survey 2015-16

\section{Crimes reported by type in Pakistan (2003-2012)}

The statistics on crime in Pakistan indicates that of extreme type of criminalities (killing, rape, theft, and attack) and property (looting, stealing of motor vehicle theft)mounted up during(2003-2012). Robbery remains higher than the other categories of crime over years. The overall stats on crime showed that crime rates goes rising in Pakistan up to 2010, after that there is slight decline in the crime rates in all categories except kidnapping.

The following table shows crime rates by type reported in Pakistan during 2003-2012.

Table 4: Crimes reported by type

\begin{tabular}{|l|l|l|l|l|l|l|l|l|l|l|}
\hline Offences & $\mathbf{2 0 0 3}$ & $\mathbf{2 0 0 4}$ & $\mathbf{2 0 0 5}$ & $\mathbf{2 0 0 6}$ & $\mathbf{2 0 0 7}$ & $\mathbf{2 0 0 8}$ & $\mathbf{2 0 0 9}$ & $\mathbf{2 0 1 0}$ & $\mathbf{2 0 1 1}$ & $\mathbf{2 0 1 2}$ \\
\hline $\begin{array}{l}\text { All } \\
\text { Reported }\end{array}$ & $\mathbf{4 0 0 6 8 0}$ & $\mathbf{4 4 0 5 7 8}$ & $\mathbf{4 5 3 2 6 4}$ & $\mathbf{5 3 7 8 6 6}$ & $\mathbf{5 3 8 0 4 8}$ & $\mathbf{5 9 2 5 0 3}$ & $\mathbf{6 1 6 2 2 7}$ & $\mathbf{6 5 2 3 8 3}$ & $\mathbf{6 7 3 7 5 0}$ & $\mathbf{6 4 6 9 0 0}$ \\
\hline Murder & 9346 & 9719 & 9631 & 10048 & 10556 & 12059 & 12491 & 13208 & 13860 & 13846 \\
\hline $\begin{array}{l}\text { Attempted } \\
\text { Murder }\end{array}$ & 11562 & 12678 & 12863 & 13729 & 13840 & 15083 & 14962 & 15478 & 15496 & 15338 \\
\hline $\begin{array}{l}\text { Kidnapping/ } \\
\text { Abduction }\end{array}$ & 8450 & 9637 & 9209 & 10431 & 10725 & 15135 & 16313 & 18556 & 19806 & 20194 \\
\hline Dacoity & 1821 & 2338 & 2395 & 2895 & 3260 & 4529 & 4457 & 4727 & 4980 & 4259 \\
\hline Robbery & 8434 & 11851 & 12199 & 14630 & 16639 & 19943 & 19138 & 21907 & 20632 & 17081 \\
\hline Burglary & 13049 & 13647 & 12067 & 12872 & 12067 & 14943 & 15073 & 16638 & 18195 & 17638 \\
\hline Cattle theft & 6742 & 7924 & 11884 & 13327 & 9388 & 8880 & 9456 & 8373 & 9345 & 9046 \\
\hline Other theft & 20189 & 22024 & 24793 & 31166 & 29473 & 36023 & 35697 & 37878 & 42223 & 40102 \\
\hline Others & 321087 & 350760 & 358223 & 428768 & 432100 & 465908 & 488640 & 515618 & 529213 & 509396 \\
\hline
\end{tabular}


Figure 4: Crimes reported by type in Pakistan

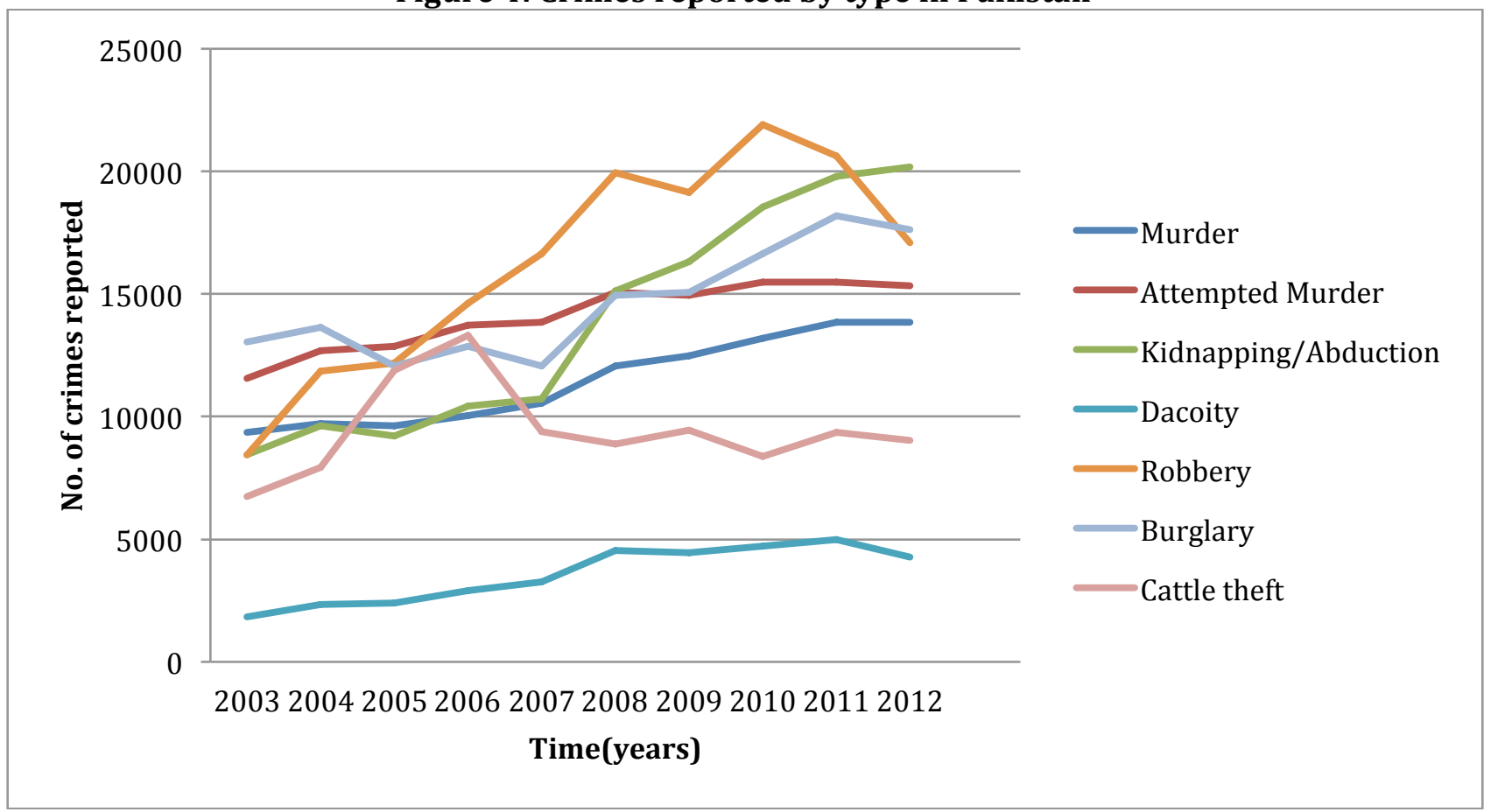

The Model

\section{METHODOLOGY}

In this exploration extend keeping in mind the end goal to break down the relationship of instruction and wrongdoing, we are utilizing direct relapse display. Direct relapse, otherwise called basic straight relapse or bivariate direct relapse is utilized when we need to anticipate the estimation of a reliant variable in light of the estimation of a free factor. We demonstrate to you generally accepted methods to complete straight relapse utilizing Stata, and also translate and report the outcomes from this test. Along these lines to examine the relationship of instruction and wrongdoing, we assessed taking after condition:

$$
Y_{t}=\alpha_{0}+\alpha_{1} X_{t}+u_{t}
$$

$\mathrm{Y}_{\mathrm{t}}=$ Crime rate

$\mathrm{X}_{\mathrm{t}}=$ Enrollment at higher level

$\alpha_{0}=$ Constant term

$\mathrm{u}_{\mathrm{t}}=$ Error term

\section{Hypothesis}

In this study we are analyzing the following hypothesis:

$\mathbf{H}_{0}$ : Education does not have significant impact on crime.

$\mathbf{H}_{1}$ : Education does have significant impact on crime.

\section{Data Sources}

The information for advanced education (Enrollment at Higher Level) that we will examine has been taken from different issues of Pakistan Economic Survey. The nation that has been decided for this experimental test is the Pakistan and chose day and age ranges (20032012).The information for crime has been taken from department of Police Research and 
Development Ministry of Interior. A yearly recurrence has been utilized, since it is the most sensible given the need to watch changes in Crime after some time.

\section{EMPIRICAL ANALYSIS AND RESULTS}

The initial phase in this examination worries to inspect the relationship of the Crime and Education arrangement. For the greater part of the arrangement the invalid speculation $\mathrm{HO}$ of insignificant can be rejected at a 5\% confidence level. For this we need to run the regression line in "STATA" software (Version 12) is as per the following.

regress NoofCrime EnrollmentofEducation 000s
\begin{tabular}{r|crcc} 
Source & SS & df & MS \\
\hline $\begin{array}{r}\text { Model } \\
\text { Residual }\end{array}$ & $\begin{array}{r}6.7007 \mathrm{e}+10 \\
1.8016 \mathrm{e}+10\end{array}$ & $\begin{array}{r}1 \\
8\end{array}$ & $\begin{array}{l}6.7007 \mathrm{e}+10 \\
2.2520 \mathrm{e}+09\end{array}$ \\
\hline Total & $8.5024 \mathrm{e}+10$ & 9 & $9.4471 \mathrm{e}+09$
\end{tabular}

$$
\begin{array}{lrr}
\text { Number of obs } & = & 10 \\
\text { F( 1, 8) } & = & 29.75 \\
\text { Prob }>\text { F } & = & 0.0006 \\
\text { R-squared } & = & 0.7881 \\
\text { Adj R-squared } & = & 0.7616 \\
\text { Root MSE } & = & 47456
\end{array}
$$

\begin{tabular}{|c|c|c|c|c|c|c|}
\hline NoofCrime & Coef. & Std. Err. & $\mathrm{t}$ & $P>|t|$ & [95\& Conf. & Interval] \\
\hline EnrollmentofEducation $000 \mathrm{~s}$ & .2223401 & .0407608 & 5.45 & 0.001 & .1283454 & .3163348 \\
\hline _cons & 365677.5 & 37850.19 & 9.66 & 0.000 & 278394.8 & 452960.2 \\
\hline
\end{tabular}

The yield comprises of four imperative bits of data: (a) the R2 esteem ("R-squared" column) speaks to the extent of change in the needy variable that can be clarified by our autonomous variable (in fact it is the extent of variety represented by the relapse display well beyond the mean model). Notwithstanding, R2 depends on the specimen and is a decidedly one-sided gauge of the extent of the change of the needy variable represented by the relapse demonstrate (i.e., it is too huge); (b) a balanced R2 esteem ("Adj R-squared" line), which rectifies positive predisposition to give an esteem that would be normal in the populace; (c) the $F$ esteem, degrees of flexibility ("F $(1,8) "$ ) and factual centrality of the relapse show ("Prob > F" line); and (d) the coefficients for the steady and free factor ("Coef." segment), which is the data you have to anticipate the needy variable, Crime rate, utilizing the autonomous variable, Enrollment of Higher Education.

In this case, $\mathrm{R} 2=0.7881$. Balanced $\mathrm{R} 2=0.7616$ (to 3 d.p.), which implies that the autonomous variable, Enrollment of Higher Education, clarifies $76.16 \%$ of the inconstancy of the reliant variable, Crime rate, in the populace. Nonetheless, regularly it is R2 not the balanced R2 that is accounted for in results. In this case, the relapse model is measurably noteworthy, $F(1,8)$ $=29.75, \mathrm{p}=0.0006$. This demonstrates, general, the model connected can measurably altogether foresee the reliant variable, Crime rate. The strong conclusion, there is certain relationship amongst crime and, Enrollment of Higher Education.

\section{CONCLUSION}

This study has examined the effects of higher education on criminal activities in Pakistan for the 2003-20012 period, using linear regression analysis. The study has found positive relation between higher education and criminal activities. The estimated coefficient has strong and positive impact which explains $78 \%$ variation on crime rate in Pakistan. Also the results showed that one unit increase in enrolment at higher education level increases crime rate by 0.22 units. This study conclude that sufficient opportunities provided by private and public 
sector to adjust all the educated people can yield significant social advantages and can be a key approach device in the drive to diminish crime .An $20 \%$ increased ratio of higher education has lead the country to decrease $22 \%$ of its crime rate .

\section{References}

Steurer, S. J., \& Smith, L. G. (2003). Three-State recidivism study: Executive summary. Correctional Education Association (Lanham, MD) and Management Training Corporation Institute (Centerville, UT).

Lance Lochner and Enrico Moretti. (2004). The Effect Of Education On Crime: Evidence From Prison Inmates, Arrests, And Self-Reports. American Economic Review, 94, 155-189.

Bazos, A., \& Hausman, J. (2004). Correctional education as a crime control program. UCLA School of Public Policy and Social Research, Department of Policy Studies.

Moretti, E. (2005, October). Does Education Reduce Participation In Criminal Activities? In symposium on "The Social Costs of Inadequate Education"(Columbia University Teachers College.

Feinstein, L., \& Sabates, R. (2005). Education and youth crime: effects of introducing the Education Maintenance Allowance programme. Available at SSRN 901421.

Lochner, L. (2008). Education and Crime. International Encyclopedia of Education.

Lochner, R. H. $(2012,08)$. The Impact of Education on Crime: International Evidence.

Machin, Stephen, Olivier Marie, and Sunčica Vujić. (2010). The Crime Reducing Effect of Education. The Economic Journal, 463-484.

Rajesh, M. (2015). Regional Cooperation Among Open Universities: A Case Of South Asia.

Economic Survey of Pakistan (2015-2016)

Almlund, M., Duckworth, A. L., Heckman, J. J., \& Kautz, T. D. (2011). Personality psychology and economics (No. w16822). National Bureau of Economic Research.

Hjalmarsson, R., Holmlund, H., \& Lindquist, M. J. (2015). The Effect of Education on Criminal Convictions and Incarceration: Causal Evidence from Micro-data. The Economic Journal, 125(587), 1290-1326.

Mendelson, M. (2009). Why we need a First Nations education act.

Dearden, L., Emmerson, C., Frayne, C., \& Meghir, C. (2009). Conditional cash transfers and school dropout rates. Journal of Human Resources, 44(4), 827-857.

Kleiman, M. (2009). When brute force fails: How to have less crime and less punishment. Princeton University Press.

Goldin, C. D., \& Katz, L. F. (2009). The race between education and technology. Harvard University Press.

Mishel, L., Bivens, J., Gould, E., \& Shierholz, H. (2012). The state of working America. Cornell University Press.

Braithwaite, J. (2002). Restorative justice \& responsive regulation. Oxford University Press on Demand.

Attanasio, O. P., Meghir, C., \& Santiago, A. (2012). Education choices in Mexico: using a structural model and a randomized experiment to evaluate Progresa. The Review of Economic Studies, 79(1), 37-66.

Richards, J. (2016). ON-RESERVE SCHOOLS: AN UNDERPERFORMING "NON-SYSTEM". Canada: The State of the Federation, 2013: Aboriginal Multilevel Governance, 279.

Meghir, C., Palme, M., 疇 rten, \& Schnabel, M. (2012). The effect of education policy on crime: an intergenerational perspective (No. w18145). National Bureau of Economic Research.

Cunha, F., Heckman, J. J., \& Schennach, S. M. (2010). Estimating the technology of cognitive and noncognitive skill formation. Econometrica, 78(3), 883-931.

Cunha, F., \& Heckman, J. (2007). The technology of skill formation (No. w12840). National Bureau of Economic Research.

Hjalmarsson, R., Holmlund, H., \& Lindquist, M. J. (2015). The Effect of Education on Criminal Convictions and Incarceration: Causal Evidence from Micro-data. The Economic Journal, 125(587), 1290-1326.

Imbens, G. W., \& Wooldridge, J. M. (2009). Recent developments in the econometrics of program evaluation. Journal of economic literature, 47(1), 5-86. 